Tips om medisinsk litteratur, andre bøker, filmer og elektroniske medier

som bør anmeldes, sendes tidsskriftet@legeforeningen.no

\section{Verdifullt supplement om lungesykdommer}

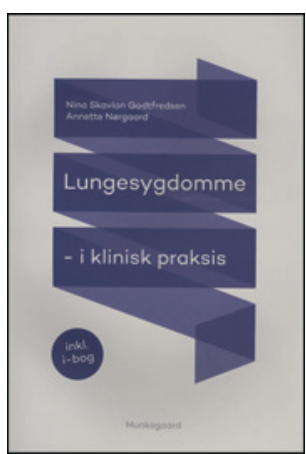

Nina Skavlan Godtfredsen, Annette Nørgaard Lungesygdomme i klinisk praksis

350 s, tab, ill. København: Munksgaard, 2016. Pris DKK 340

ISBN 978-87-628-1460-8

Målgruppene for denne læreboken er yngre sykehusleger som er interessert i lungemedisin, men den kan også være aktuell for lungesykepleiere og medisinstudenter. Alle kapitlene er rikelig illustrert med tegninger og bilder, bokser med fakta og gode råd og oversiktlige tabeller som oppsummerer viktige poeng.

I tillegg til tradisjonelle kapitler om anatomi, fysiologi, utredning av symptomer, aktuelle undersøkelser og beskrivelser av de vanligste lungesykdommene, er det et kapittel om visittgang med gode råd til en uerfaren lege om hvordan man kan disponere tiden for å få jobben gjort på hverdager eller på helgevakt. Her inngår det også et avsnitt med forslag til strategi for en god samtale mellom lege og pasient. De fleste kapitlene inneholder sykehistorier som belyser typiske symptomer og funn som vil hjelpe leseren til å se sykdomsforløpet fra et pasientperspektiv.

Kapitlet om sykdomstegn og symptomer er praktisk rettet og vil være svært nyttig for en lege i akuttmottaket. Aktuelle lungeundersøkelser, indikasjoner, utføring og tolking av spirometri er kortfattet beskrevet. Det vil være nyttig også for leger i allmennpraksis. Kapitlet om invasive lungeundersøkelser inneholder en detaljert beskrivelse av prosedyren ved bronkoskopi og omtaler kort bronkioloalveolær lavage (BAL), transbronkial biopsi, endobronkial ultralydskanning, transtorakal nåleaspirasjonsbiopsi og torakoskopi. Prosedyrene pleuracentese, innleggelse av thoraxdren og pleurodese er utførlig beskrevet med gode praktiske råd om selve gjennomføringen av prosedyren. I kapitlet om bildediagnostikk beskriver forfatterne prinsippene ved utføring og tolking av røntgen thorax, og de gir en grundig og godt illustrert beskrivelse av klinisk lungeultralydskanning.

Den siste delen består av særskilte kapitler for kronisk obstruktiv lungesykdom (kols), astma og allergi, astma og kols overlappingssyndrom, obstruktiv søvnapnésyndrom (OSAS), interstitielle lungesykdommer, arbeidsrelatert lungesykdom, pleurasykdommer, lungeinfeksjoner og maligne lungesykdommer. Denne delen innledes av et kapittel om palliasjon av lungekreft og kols som er skrevet av Kristoffer Marså og Peter Lange. For alle leger og sykepleiere som har behandlingsansvar for pasienter med avansert, uhelbredelig lungesykdom, er dette svært nyttig og kjærkommen lærdom med gode praktiske råd om hvordan man kan kartlegge situasjonen og lage en plan for oppfølging og behandling. Begrepet «advance care planning» (ACP) introduseres sammen med råd om hvordan man best kan kommunisere med pasient og pårørende.

Boken er et verdifullt og viktig supplement til eksisterende læreboklitteratur om lungesykdommer for denne målgruppen.

\section{Solid embryologi i dansk oversettelse}

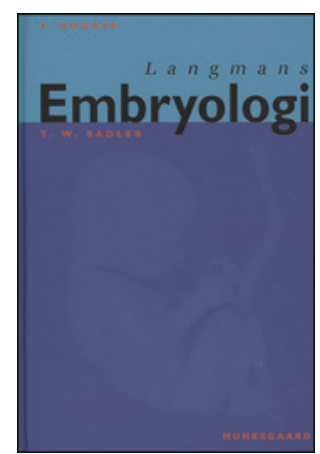

\author{
T. W. Sadler \\ Langmans embryologi
}

4. utg. 560 s, tab, ill. København: Munksgaard, 2016. Pris DKK 575

ISBN 978-87-628-1574-2

De siste 20 årene har gitt oss en mengde ny informasjon om hvordan fosteruviklingen er regulert, og dermed også hva som kan ha skjedd hvis fosteret har en utviklingsfeil. Embryologi er dermed et fag som har vært, og fortsatt er, i rivende utvikling, noe nyere utgaver av læreverkene tar hensyn til i ulik grad.

Langman's embryology ble utgitt første gang i 1964 og er rettet mot studenter i medisinsk grunnutdanning. Boken som nå må regnes som en klassiker, er siden kommet i 12 oppdaterte utgaver, sist i 2015. Det er denne 13. utgaven som nå også er oversatt til dansk.

Boken har stive permer, papir av god kvalitet og er satt opp på en tiltalende og lesevennlig måte med tilstrekkelig bred marg til å gjøre egne notater. Boken er inndelt $\mathrm{i}$ to hoveddeler, allmenn og spesiell embryologi. Allmenn embryologi handler om fosteret fra unnfangelsen til fødselen, inkludert organogenese, fosterhinner, navlestreng og placenta. Denne delen inneholder også et eget kapittel om medfødte misdannelser. Spesiell embryologi fokuserer på utviklingen av hvert enkelt organsystem, med egne avsnitt om den molekylære reguleringen knyttet til hvert organsystem.

Det er ofte først når man i klinisk arbeid møter problemstillinger som kan knyttes til utviklingsfeil i fosterlivet, at kunnskaper i embryologi fremstår som relevante. For kvinner i fertil alder vil det utvilsomt være verdifullt om allmennlegen har tilstrekkelig innsikt $i$ embryologi til å kunne forklare hva som skjer de første ukene av svangerskapet.

Den danske oversettelsen av Langman's Embryologi fremstår som en bok med appell langt utover studentenes rekker. Boken innbyr en interessert leser til lesing fra perm til perm, nærmest som en hvilken som helst engasjerende sakprosabok. Illustrasjonene er stiliserte og lette å forstå, og fotografier av fostre og kliniske eksempler understreker tekstens kliniske relevans. For leger som kommer i kontakt med pasienter der fosterutvikling er relevant (og det vil gjelde blant annet alle fastleger som møter gravide kvinner), vil denne boken kunne gi en nyttig gjenoppfrisking og oppdatering av gammel kunnskap.

Embryologi handler mye om tredimensjonal forståelse av endringene som skjer i fosteret, særlig under organogenesen. For studenter er det viktig at embryologiboken har illustrasjoner som de klarer å «lese» tredimensjonalt. Hvis valget da faller på Langmans embryologi, hadde jeg nok som student vært villig til å betale litt ekstra for å få en lærebok som også inviterer til å bli lest. Den tilsvarende engelske utgaven uten stiv perm er billigere, men ikke like innbydende.

Anne Spurkland

Professor, Avdeling for anatomi

Universitetet i Oslo 